\title{
Accounting
}

\section{The effect of total quality management on the financial performance by moderating organizational culture}

\author{
Sanaa Maswadeh ${ }^{a^{*}}$ and Rania Al Zumot ${ }^{b}$
}

a Jadara University, Jordan

${ }^{b}$ Middle East University, Jordan

\section{H R O N I C L E}

Article history:

Received: September 25, 2020

Received in revised format:

September 302020

Accepted: November 7, 2020

Available online:

November 7, 2020

Keywords:

Total Quality Management

Organizational Culture

Financial Performance

Jordanian Transport Companies

\begin{abstract}
A B S T R A C T
This study aims to learn the effect of the Total Quality Management dimensions, Top Management Support, Customer Focus, Process Management, Employees Participation, Employees' Empowerment, and Continuous Improvement, on financial performance by moderating organizational culture. The study population includes nine transport companies listed on the Amman Stock Exchange until the end of 2019. Alia Company and Royal Jordanian Airlines were excluded since its financial data formed extreme values when compared with the values of the rest of the companies. The study uses Multiple Linear Regression to test the hypotheses. The study found a statistically significant effect at the level of significance $(\alpha<0.05)$ for both top management support, customer focus, employees' participation and empowerment, by moderating the organizational culture on financial performance measured by return on asset for the Jordanian transport companies listed on the Amman Stock Exchange. In light of the statistical results, the study presented several recommendations, the most important of which was to increase the top management interest in cultivating a profound organizational culture towards learning, development, mastering performance and improving the quality of its services to attract customers, and distinguish the organization from other organizations, in a way that reflects positively on developing its financial performance.
\end{abstract}

(C) 2021 by the authors; licensee Growing Science, Canada

\section{Introduction}

The world witnessed radical changes reflected in the business sector. The substantial scientific revolution in all areas, especially in the field of communication and technology and the emergence of globalization, generated challenges for business organizations to survive. Privatization allowed new areas of investment for the private sector that were prevented in the past. As a result, we find an increase in interest among international societies in improving and managing quality. Quality became a fundamental factor in meeting the changing needs of societies. The requirement of quality management increased, and its functions have expanded, which demands capable management to enhance organizations' efficiency, investing its resources, and continuously updating it. The TQM approach is considered a modern management concept. Embracing this relatively new philosophy requires considerable attention from managers because it provides adequate solutions to develop and reform the economy (Jyoti et al., 2017; Bouranta et al., 2019).

\footnotetext{
* Corresponding author.

E-mail address:.mmsana59@gmail.com (S. Maswadeh) 
The need to make optimal use of the material and human resources compels organizations to respond to TQM requirements. Based on this, many countries of the world have given a noticeable interest in TQM in various fields and organizations. Adopting the TQM approach and implementing its various dimensions is expected to increase businesses' efficiency and productivity (Psomas \& Jaca, 2016). Total quality management has developed a qualitative shift from a culture of minimum to a culture of mastery. Development and continuous improvement enable businesses to adapt to changing circumstances. Adopting the TQM approach requires all workers to learn new skills that support the culture of change and quality revolution. Workers should possess positive values and willingness to accept the challenges imposed by the principles and requirements of applying TQM. Also, they should seriously consider their role and responsibilities towards achieving the aspirations of the beneficiary groups. There is an urgent need to review the organizational culture, goals, programs, organizational structures, and leadership to provide high-quality services and products. Furthermore, reaching a high level of quality that is compatible with changing environmental needs is a mean to achieve a competitive advantage. It reveals organizations' ability to survive by achieving the desired financial returns, which are reflected positively on their value on the financial market. Therefore, the main problem facing service provider organizations is achieving continuous improvement by exploiting the capabilities and skills of workers. This is particularly challenging with the presence of advanced communications and information technologies. Investing in evolving technologies helps in providing better services and achieving organizational goals. Creating adjustment and balance between providing consistent service and making the necessary changes in the prevailing organizational culture within the organization to produce services that meet the needs and desires of clients is a challenging, yet vital requirement to survive. Adjustment in culture and service has a reflection on the organization's ability to achieve profits, improve financial performance, expand investment and growth, and its ability to compete in local and global markets in light of the accelerating environmental conditions and developments. Perhaps the continued scientific advancement and technological development in various fields require looking at things in different ways. Generating new ideas and developing processes in a renewed and continuous manner, especially in developing countries, which strives to keep pace with scientific progress and technical development in all areas, made quality inevitable for business organizations.

Creating quality culture requires reaching a clear and comprehensive vision about standards and dimensions of total quality management. Service organizations, in particular, require the commitment of senior management to apply the required standards and specifications of quality assurance to achieve outstanding performance leading to pioneering work. Financial performance is considered one of the most critical accounting measures. It shows the extent of the company's ability to make optimal use of its resources to achieve wealth and profit. Total quality management is one of the essential modern methods that contribute to achieving a competitive advantage and improving the performance of companies. Implementing total quality management dimensions helps to increase the market share, enhance the organization strengths, and address its weaknesses. Furthermore, it enables organizations to attract a larger number of customers and find a successful way to serve their needs and requirements. Because of the importance of total quality managing and its positive reflection on performance, it has attracted the interest of management to improve organizational performance. Proper implementation of total quality management helps in achieving the organization vision, mission and strategic goals. The success of the organizations reflects on the growth and prosperity of the national economy. Hence, applying total quality management concepts aims to raise the performance efficiency of the organization and its members and increase its competitiveness by providing high-quality goods and services. Based on the above, carrying out an empirical study to explore the reality of applying TQM concepts and dimensions in service providing organizations has become an urgent need to adapt better in dealing with global changes as a means to grow and survive. There is a need to study total quality management and its impact on financial performance in terms of continuous improvement, employee engagement, and customer focus. In light of the increased customers' awareness and consciousness to distinguish between good and poor service quality, it is vital to study the factors that drive the organization to apply the dimensions of total quality management, including organizational culture change to embrace quality and improve performance (Aquilani et al., 2017). Quality is an essential requirement because it supports the strength of any organization and distinguishes it from other organizations. The service sector adopts quality as a resolute means to support all the activities that it performs, and to ensure continuous progress in various fields to meet the needs and desires of customers. Quality reflects organizations' ability to achieve profits, improve its financial performance, the profitability of its shares and expand its investment, growth, and ability to compete in local and global markets in light of the accelerating environmental conditions and developments.

In this study, listed transport companies on the Amman Stock Exchange were chosen from within the services sector to reach accurate results that are generalizable to the study community. The transportation sector is considered an essential pillar in the Jordanian economy. The transportation sector grows at an annual rate of $6 \%$ and employs approximately $7.6 \%$ of the Jordanian workforce, which produces about 126,000 jobs annually (Jordan Investment Commission, 2019). This study contributes to strengthening the theoretical framework concerning total quality management especially that this topic is one of the vital and modern issues that many studies have addressed. Additionally, Arab libraries are lacking in such studies investigate the reality of applying the dimensions of total quality management in Jordanian service companies in light of the available capabilities. Moreover, it examines the impact of implementing the quality dimensions on financial performance by mediating organizational culture as a critical factor for the successful application of Total Quality Management. 
The practical contribution stemmed from the participation of this study in providing reliable information to official authorities. It is also expected to help the managing authorities of service sectors, including Jordanian transportation companies in determining the dimensions of the total quality that lead to improvement and development in performance and customer service, and to make fundamental changes in the style of management. This determination of dimensions helps managements to achieve excellence in providing services and facing competitors and thus helping them to develop strategies and future policies to achieve the set goals. Finally, it is expected to benefit from the results of the study by providing recommendations to the educational institutions, researchers, and those interested in quality to implement the dimensions of Total Quality Management in various fields and sectors through adapting the quality to the organizational culture.

\section{Literature review and the development of study hypotheses}

In this rapidly changing world and unstable business environment, as well as demanding and aware customers, the application of TQM has become a necessity for the survival of both industrial and service business organizations (Chuang et al., 2015; Wamalwa et al., 2017; Pattanayak et al., 2017). The impact of implementing TQM is positively related to higher financial performance (Parvadavardini et al., 2016; Nuryani et al., 2016; Khudhair et al, 2019), although some studies claim that the effect on financial performance is more intense in smaller firms (Bu \& Cao, 2015). Fotopoulos and Psomas, (2009) suggested that Embracing "soft" TQM helps in strengthening the position of organizations in the market. Top management support or leadership, customer focus, process management, employees' participation, employees' empowerment, and continuous improvement are among the soft TQM elements. While the "hard" TQM elements are management tools and techniques such as flow charts, relations diagram, scatter diagram, control charts, and so on. Creating a quality culture in organizations depends on the first place on top management (Young \& Poon, 2013). Management conveys quality culture to employees by communicating organizational values and influencing the employees to embrace quality concepts. Continues support of management is essential to succeed in implementing TQM concepts. Supportive management must provide guidance, improve, and empower employees while executing policies and procedures to ensure the organization is well protected (Parumasur, 2013). Top management plays the principal role in directing employees in its various departments toward customer focus. Customer focus is the ability and willingness of all employees to respond quickly to customers' needs and requirements. Gavareshki et al. (2019) propose that surviving in competitive markets and maximizing profits are foremost concerns for any commercial organization. Businesses are obliged to focus their attention on customers to reach their organizational goals. Meeting TQM standards and compel to its requirements helps in achieving better performance. However, the level of customer focus depends mostly on the prevailing culture.

Evade failures is a fundamental part of pursuing a better focus on customers and gaining their satisfaction and loyalty; the right processes management can achieve this goal. The employees in all organizations handle many processes in their daily conduct. Thus, Organizations should manage those processes to be effective. (Kaplan et al., 2001). Treating work as a process help in improving it, Davenport, (2015, pp 18) declares "To treat something as a process is to impose a formal structure on it - to identify its beginning, end, and intermediate steps, to clarify who the customer is for it, to measure it, to take stock of how well it is currently being performed, and ultimately to improve it." As noted from the above argument, the role of employees is stressed out in all aspects of implementing TQM elements. Empowering the employees to achieve quality goals is inevitable. The empowerment and the participation of employees create positive attitudes toward the organization and influence the establishment of quality culture. Quality embracing by all employees helps in improving overall organizational performance (Fening et al., 2016). Employees' participation and empowerment encourage them to engage in continues improvement of processes, services, and products to achieve customer satisfaction. Continues improvement was the fifth principle of Deming's fourteen key principles for management, which was later, associated with TQM, although he did not use the term. The principle states "Improve constantly and forever the system of production and service, to improve quality and productivity, and thus constantly decrease costs" (Deming, 1991). Many studies have confirmed the effect of organizational culture on financial performance (Melo, 2012; Al-Swidi \& Mahmood, 2012; Golafzani \& Chirani, 2016; Zadeh, 2016; Nuryani et al., 2016). On the other hand, Siehl and Martin (1989) designate some reservations in linking organizational culture to financial performance; they considered it as problematic and lacked precision. More explicitly, Yesil and Kaya (2013); Idrus et al. (2015) found no significant effect of organizational culture dimensions on financial performance.

In light of the previous studies and the literature review, the study presented the main null hypothesis of the study as follows:

"There is no statistically significant difference to the TQM dimensions, Top management commitment, customer focus, process management, employee participation and empowerment, continuous improvement, on the financial performance of Jordanian transportation companies, attributed to the organizational culture as moderating variable".

The following diagram clarifies the assumption of the study: 


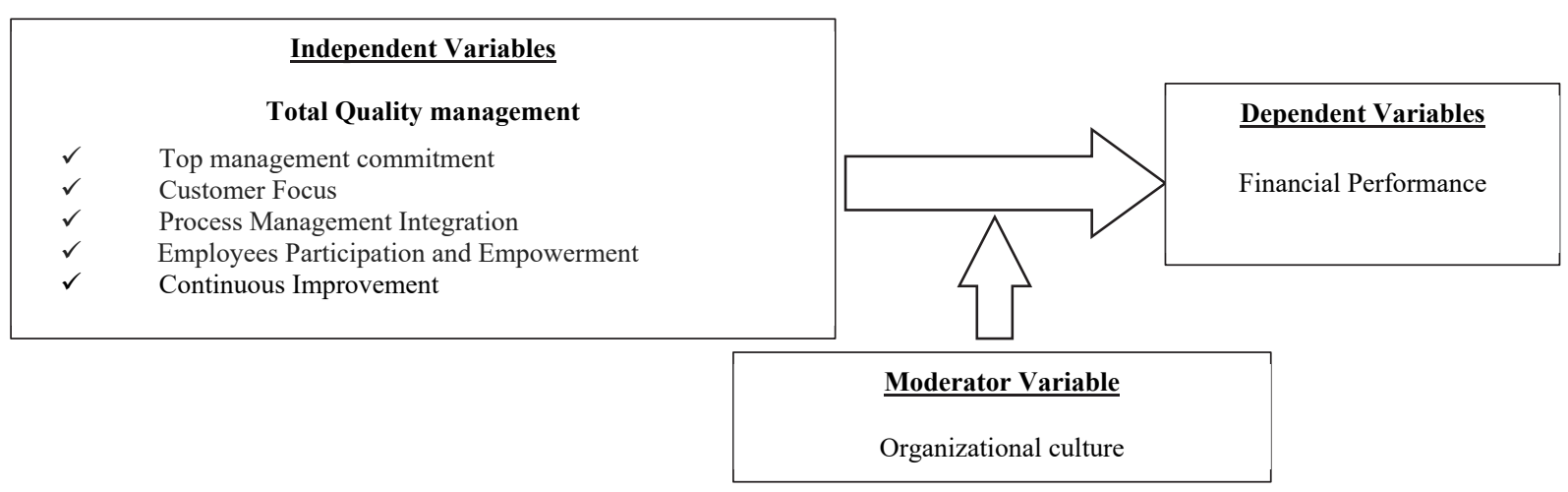

\section{Methodology}

This section includes an analytical presentation of the methodology used in the study and outlines the stages and steps used to test the study hypotheses to achieve the desired goals. The first part addresses the study population and the study sample. The second part declares the sources of information and data collection. The last parts state the study variables and the statistical methods used in analyzing the data and test study hypothesis.

\subsection{Population and study sample}

The study population consists of the nine listed transportation companies on the Amman Stock Exchange until the end of 2019. A random sample of 8 companies was selected from the transportation sector. Royal Jordanian Airlines was excluded because its financial data formed extreme values compared with the rest of the companies. To obtain close to natural distribution and homogeneous data; the transportation sector data was selected within the Jordanian services sectors to ensure the homogeneity of the data within one industry. Studying the data of companies from different sectors leads to significantly scattered values and therefore, to a non-natural distribution of study data.

\subsection{Sources of data collection}

To achieve its goals and test its hypothesis; the study depended on the annual financial reports of the Jordanian transportation companies listed on the Amman Stock Exchange during the period (2011-2019). The data were obtained from the Amman Stock Exchange website, in addition to a questionnaire distributed to the directors of departments and divisions in Jordanian transportation companies, to measure the overall quality dimensions and organizational culture. Questionnaires were distributed using the simple random sampling method were 80, of which, (78) questionnaires were retrieved, (5) questionnaires were not valid due to a repetition of the same answer, or a significant lack of information. The total numbers of valid questionnaires were (72) whereby the questionnaires were equal to the financial performance items that were extracted from the financial reports of the transportation companies, which numbered 72 and produced by eight transportation companies, over nine years.

\subsection{The study tool}

The study tool consisted of a questionnaire that included: demographic variables for managers of departments and divisions in Jordanian transportation companies, including age, educational qualification, years of experience, and professional certificates in addition to the six study dimensions as follows:

(8) Questions for Top Management Commitment, (10) Questions for Customer Focus, (7) Questions for Process Management Integration, (9) Questions for Employees Participation and Empowerment, (10) Questions for Continuous Improvement, and (10) Questions for the dimension of organizational culture. The total number of questions was 54 questions. The items were utilized to measure the effect of total quality management on the financial performance using the return on assets, by moderating organizational culture. The return on assets data were obtained from published financial reports of the Amman Stock Exchange.

The researchers used a five-point Likert Scale to determine the degree of approval of the study sample individuals on each of the paragraphs of the study questionnaire. The answers were converted into quantitative data, and the relative weights were given from 1-5, where five represents strongly agree, four agree, 3 moderately agree, two disagree, and one strongly disagree.

\subsection{Statistical methods used in data analysis}

The study used several statistical methods to achieve the goals of the research and test its hypotheses as follows: 
- Reliability Test: Use the Cronbach alpha test to verify the internal consistency of the answers of the members of the study sample to the questionnaire questions as one of the indicators of its stability.

- One Sample t-test: To calculate the mean of the responses of the members of the study sample to the mean value (test mean), which is (3) given that the study scale of trends was five, and there is an agreement on application of the dimension of total quality management when the level of significance is five percent (i.e. Sig $\leq 5 \%$ ).

- Multicollinearity- Test: to verify linear intervention between the independent variables of the study.

- Multiple Linear Regressions: To test the hypothesis related to studying the effect of total quality dimensions on the financial performance of Jordanian transportation companies. The study models were formulated in the form of regression equations linking the dimensions of total quality management as independent variables and return on assets as a dependent variable, by moderating, the organizational culture of the companies. The following are the multiple regression models that the current study relied on:

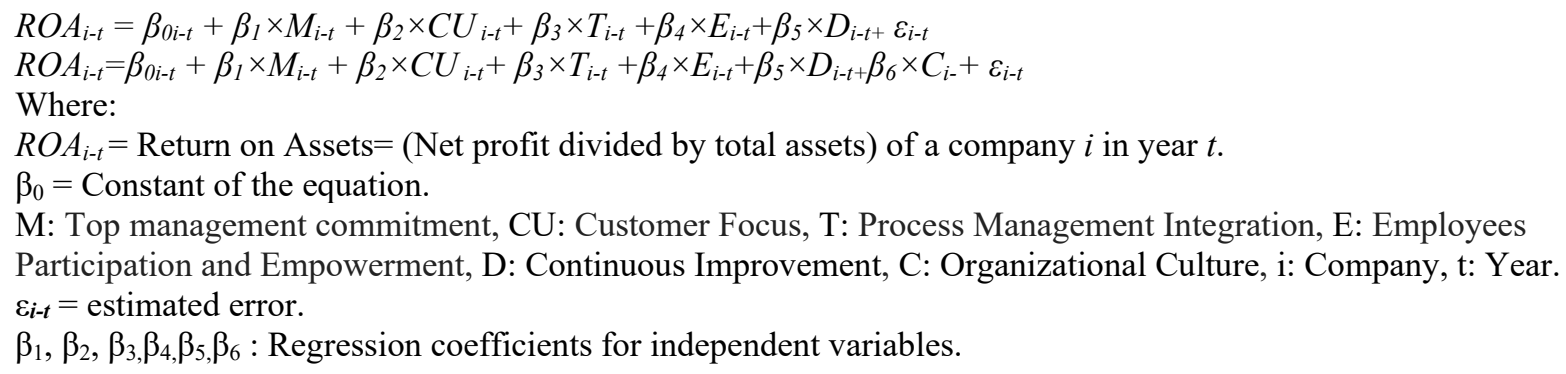

\section{Statistical results}

This part deals with analyzing the demographic data of the study sample members. It presents the results of analyzing the opinions of the study sample about the reality of applying total quality management in Jordanian transportation companies. Also testing data validity for regression analysis, then testing the hypothesis that the study covered by relying on multiple linear regression to test the effect of total quality management's dimensions on the financial performance in the Jordanian transportation companies.

\subsection{Demographic data analysis}

After calculating the Distribution Frequency and Percentages related to the characteristics of the members of the study sample, it was noted that the majority of the ages of the study sample ranged between (30-40) years. The years of work experience showed that (71\%) of the study sample have more than (5) years of experience, and it was found that most of the study sample members are holders of a (bachelor's) degree with a percentage of (75\%). Concerning Professional certificates; CMA certification accounts for 18\%, followed by JCPA (Jordan Certified Public Accountant) at a percentage of 15\%. By reviewing the demographic characteristics of the study sample, it can be concluded that there is sufficient scientific and practical knowledge of the study participants that qualify them to answer the questions of the study questionnaire.

\subsection{The stability of the study questionnaire}

The internal consistency factor (Cronbach Alpha) was used to ensure the stability of the questionnaire concerning the answers of the members of the study sample on all dimensions of applying TQM, and they were as follows:

\section{Table 1}

Internal reliability of study questionnaire

\begin{tabular}{lcc}
\hline Total Management Quality perspectives & \# of Items & Cronbach Alpha \\
\hline Top Management Support & 8 & 0.878 \\
Customer Focus & 10 & 0.605 \\
Process Management & 7 & 0.686 \\
Employees Participation and Empowerment & 9 & 0.734 \\
Improvement and development & 10 & 0.724 \\
Organizational Culture & 10 & 0.827 \\
Whole reliability of study instrument & $\mathbf{5 4}$ & $\mathbf{0 . 8 9 6}$ \\
\hline
\end{tabular}

Source: Result Output from SPPS Statics Analysis 
Referring to Table 1 the internal consistency coefficient Cronbach Alpha for all dimensions of Total Quality Management is (0.896). This ratio is a statistically acceptable coefficient and indicates the consistency and stability of the responses of the study participants to the questions. Sekaran and Bougie (2016) recommended that the accepted ratio of the statistically stable coefficient is $(0.60)$ or more. This condition has been applied to all dimensions of total quality management (Top management commitment, Customer Focus, Process Management Integration, Employees Participation and Empowerment, Continuous Improvement and Organizational Culture). The above results are considered an indication of consistency and stability regarding the participants' answers on the questionnaire.

\subsection{One Sample T-test results}

This part presents the most important statistical results related to One-Sample t- (test). To identify the reality of applying Total Quality dimensions and organizational culture from the study sample members' view of point; the test results were as follows:

\section{Table 2}

One Sample T-test results of applying Total Quality dimensions and organizational culture.

\begin{tabular}{|c|c|c|c|c|}
\hline Items & Mean & Std Deviation & T - Value & Sig \\
\hline Top Management Support & 3.39 & 0.74 & 39.33 & 0.00 \\
\hline Customer Focus & 3.92 & 0.37 & 89.49 & 0.00 \\
\hline Process Management & 3.89 & 0.48 & 68.57 & 0.00 \\
\hline Employees Participation and Empowerment & 3.72 & 0.51 & 62.78 & 0.00 \\
\hline Improvement and development & 3.69 & 0.49 & 64.65 & 0.00 \\
\hline Organizational Culture & 3.57 & 0.66 & 46.15 & 0.00 \\
\hline
\end{tabular}

Source: Result Output from SPPS Statics Analysis

Referring to Table 2, The point of view of the participants on all dimensions of TQM, in addition to the organizational culture dimension achieved a mean that exceeds the average test value of (3). A significant difference with statistical significance (a $\leq 0.05$ ), is an indicator that the TQM dimensions are applied in light of an evident organizational culture in Jordanian transportation companies. This encouraged the researchers to study the effect of TQM dimensions on the financial performance of Jordanian transportation companies by moderating the organizational culture of the company.

\subsection{Test normal distribution and Multi-collinearity Test}

To test the relevance of the data to the multiple regression; the data must be distributed naturally, and there should not be a linear interference between the independent variables of the study. Depending on the Central Limit Theory, it is permissible to assume that the normal distribution condition is achieved for large samples ( $\mathrm{n}>30)$. We can assume the normal distribution of data, given that the number of observations in the study (72) items (Johnson, 2004). To verify the absence of the Multicollinearity test; a Variance Inflationary Factor (VIF) and Tolerance Index were used, as shown in Table 3, as follows:

Table 3

Multi-collinearity Test to independent variables

\begin{tabular}{ccc}
\hline Variables & VIF & \\
\hline Top Management Support & 0.542 & 1.844 \\
Customer Focus & 4.236 & 4.710 \\
Process Management & 0.236 & 0.212 \\
Employees Participation and Empowerment & 0.553 & 2.447 \\
Improvement and development & 0.409 & 1.218 \\
\hline
\end{tabular}

Source: Result Output from SPPS Statics Analysis

A review of Table 3 concerning the VIF and Tolerance shows that all values of independent variables obtained VIF values less than (5), and the tolerance factor was more than (0.20). Therefore, it is clear that there is no Multi-collinearity problem between the independent variables in the study models subject to multiple linear regression analysis (Luo et al., 2007).

\subsection{Test the hypotheses of the study}

To test the TQM effect represented by (Top management commitment, Customer Focus, Process Management Integration, Employees Participation and Empowerment, Continuous Improvement and Organizational Culture) on financial performance by moderating organizational culture variable in Jordanian transportation companies.

Depending on the multiple regression models, the results are shown in Table 4 as follows: 


\section{Table 4}

The results of testing the impact TQM on financial performance as measured by the return on assets

\begin{tabular}{|c|c|c|c|c|c|c|}
\hline & \multicolumn{3}{|l|}{ Model 1} & \multicolumn{3}{|c|}{$\begin{array}{c}\text { Model 2 } \\
\text { (Moderating organizational culture) }\end{array}$} \\
\hline & B & $\mathbf{T}$ & Sig $(T)$ & B & $\mathbf{T}$ & $\operatorname{Sig}(T)$ \\
\hline Constant & -0.151 & -1.017 & 0.313 & -0.239 & -2.187 & 0.032 \\
\hline Top Management Support & 0.053 & 2.819 & 0.037 & 0.096 & 5.944 & 0.000 \\
\hline Customer Focus & 0.071 & 2.267 & 0.027 & 0.08 & 2.277 & 0.012 \\
\hline Process Management & 0.016 & 0.551 & 0.584 & -0.024 & -0.618 & 0.539 \\
\hline Employees Participation and Empowerment & 0.078 & 2.691 & 0.009 & 0.089 & 2.731 & 0.000 \\
\hline Improvement and development & -0.006 & -0.155 & 0.877 & -0.01 & -0.191 & 0.849 \\
\hline Organizational Culture & & & & 0.031 & 2.094 & 0.040 \\
\hline $\mathbf{R}^{2}$ & \multicolumn{3}{|c|}{0.484} & \multicolumn{3}{|c|}{0.611} \\
\hline Adjust $\mathbf{R}^{2}$ & \multicolumn{3}{|c|}{0.454} & \multirow{2}{*}{\multicolumn{3}{|c|}{0.576}} \\
\hline $\mathbf{F}$ & \multirow{2}{*}{\multicolumn{3}{|c|}{12.922}} & \multirow{2}{*}{\multicolumn{2}{|c|}{17.896}} & \\
\hline Sig (F) & & & 0.000 & \multicolumn{2}{|c|}{0.000} & \\
\hline
\end{tabular}

The results of Table 4 indicate that the effect of TQM on financial performance as measured in return on assets was statistically significant. The value of $(\mathrm{F})$ was $(12.922)$ at the level of significance (Sig $=0,000)$; this confirms the significance of the regression at $(\alpha \leq 0.05)$. The value of the adjusted explanatory coefficient (Adjust $\mathrm{R}^{2}=0.454$ ), which means that the dimensions of total quality management combined (Top management commitment, Customer Focus, Process Management Integration, Employees Participation and Empowerment, Continuous Improvement and Organizational Culture) have explained (45.4\%) of the variation in financial performance, with other factors remaining constant. In the second model, the effect of total quality management on return on assets was measured by moderating organizational culture. The value of (F) was (17.896) at the level of significance ( $\mathrm{Sig}=0.000)$; this confirms the significance of the regression at $(\alpha \leq 0.05)$. Also, the value of the adjusted explanatory coefficient (Adjust $\mathrm{R}^{2}=0.576$ ); this means that total quality management has interpreted $(57.6 \%)$ of the variation in financial performance with an increase of $12.2 \%$.

Based on the above, we accept the alternative hypothesis, which states: "There is a statistically significant difference to the TQM dimensions, Top management commitment, customer focus, process management, employee participation and empowerment, continuous improvement, on the financial performance of Jordanian transportation companies, attributed to the organizational culture as moderating variable".

These findings indicate that combining the dimensions of total quality management (Top management commitment, Customer Focus, Process Management Integration, Employees Participation and Empowerment, Continuous Improvement) by moderating the organizational culture significantly affect financial performance as measured by return on assets in Jordanian transportation companies. This result was consistent with the study of Parvadavardini et al., 2016; Nuryani et al., 2016; Khudhair et al., 2019; which concluded that implementing TQM dimensions affect firms' financial performance. On the other hand, this result contrasted with the study of $\mathrm{Bu} \& \mathrm{Cao}, 2015$, which states that the effect of implementing TQM dimensions is limited to smaller firms. Referring to Table 4, it was found that Top management support in the model (2) had a significant effect, as the value of (B) reached $(\mathrm{B}=0.096)$ at a significant level $(\mathrm{Sig}=0.000)$. This value indicates that there is a significant effect of Top management support on the financial performance of Jordanian transportation companies. This result was consistent with the study of Young and Poon, (2013) and Parumasur, (2013), which concluded that Top management support plays a vital role in improving financial performance by implementing TQM dimensions. Furthemore, there is no evidence of studies that contrasted with these findings. It is apparent from Table 4 that Customer Focus in the model (2) had a significant effect, as the value of B reached $(\mathrm{B}=0.08)$ at a significant level $(\mathrm{Sig}=0.012)$. This value indicates that there is a significant effect of customer focus on the financial performance of Jordanian transportation companies. This result was consistent with the study of Gavareshki et al. (2019) and Lado et al. (2011), which concluded that Customer Focus positively affects firms' financial performance. At the same time, some studies agreed that there is an indirect effect of Customer focus on financial performance (e.g. Cai, 2009).

Referring to Table 4, it was found that employees' participation and empowerment in the model (2) had a significant effect, as the value of $(\mathrm{B})$ reached $(\mathrm{B}=0.089)$ at a significant level $(\mathrm{Sig}=0.000)$. This value indicates that there is a significant effect of Employees Participation and Empowerment on the financial performance of Jordanian transportation companies. This result was consistent with the study of Fening et al. (2016) and Baird et al. (2018), which concluded that Employees Participation and Empowerment affect financial performance. While many studies related Employees Participation and Empowerment to better employee performance which is indirectly related to better financial performance (e.g., Kiambati, et al., 2018; Saleem et al., 2019). Table 4 shows that organizational culture in the model (2) had a significant effect, as the value of (B) reached ( $B=0.031)$ at a significant level $(\mathrm{Sig}=0.040)$. This value indicates that there is a significant effect of organizational culture on the financial performance of Jordanian transportation companies. This result was consistent with other studies (Melo, 2012; Al-Swidi \& Mahmood, 2012; Golafzani \& Chirani, 2016; Zadeh, 2016; Nuryani et al., 2016) which concluded that Organizational Culture 
affects the financial performance. These results contrasted with the study of Yesil and Kaya (2013) and Idrus et al. (2015), which considered the effect of organizational culture dimensions on financial performance as insignificant and uncertain.

\section{Findings and conclusions}

In light of the statistical analysis, the study reached many results, the most prominent of which are:

- Business organizations must spread, and reflect their organizational culture in all their plans, operations and organizational structure. Furthermore, Total Quality Management should be considered part of the organization's culture and became a lifestyle and culture among all employees, applied through behavior and operational practices in all activities of the organization.

- Top management must amend its strategic objectives so that quality becomes a strategic goal at every administrative level and emphasize it as a basis and a reliable measure for evaluating the performance of employees.

- Business organizations must provide effective communication channels between the employees and customers; the feedback helps to know customers' complaints and suggestions about the service provided. Also, updating the company's electronic platforms from time to time to introduce the customers to the new services and to identify their needs for the services offered to maintain its customers and increase its ability to achieve profits and continuity in the local and global markets.

- Involving employees in finding appropriate solutions to the problems they may face while carrying out their duties through teamwork, initiative and collective consultation, in a way that increases the quality of services provided to clients, and increases the organization's ability to achieve competitive advantage and achieve the desired profits.

The researchers presented a set of conclusions in light of the statistical results, the most prominent as follows,

- Increasing the top management interest in cultivating a profound organizational culture towards learning, development, mastering performance and improving the quality of its services to attract customers, and distinguish the organization from other organizations, in a way that reflects positively on developing its financial performance.

- Increasing the top management interest in implementing its activities and operations to achieve the requirements of Total Quality Management of the service provided. This implementation includes re-engineering all its activities and processes in a manner that ensures the elimination of unnecessary activities that have no added value. Top management must develop the job description to meet the requirements of implementing the activities and processes in the organization to be updated and developed continuously and periodically to achieve the required quality performance.

- Management must follow-up the necessary technological developments and improvements in the field of the service provided continuously and periodically, and the provision of an information system to follow up on market mechanisms and economic changes that occur regularly and continuously.

The study was applied to the Jordanian transport sector within the Jordanian services sector, and the study was carried out during the year 2019, financial data was collected for the period between (2011-2019).

The researchers encourage future schoolers to apply the study on other sectors other than this study. Further, to apply it at an international level and compare the results with the local studies. Also, moderating new variables, including organizational loyalty and others and besides, conducting studies based on recent financial or non-financial performance measures to enhance the results of this study.

\section{Acknowledgment}

The authors are grateful to the Jadara University, Irbid, Jordan for the moral and incentives support granted to publish this research article. The authors are grateful to the Middle East University, Amman, Jordan for the financial support granted to cover the publication of this research article.

\section{References}

Al-Swidi, A. K., \& Mahmood, R. (2012). Total quality management, entrepreneurial orientation and organizational performance: The role of organizational culture. African Journal of Business Management, 6(13), 4717. http://www.academicjournals.org/AJBM. doi: 10.5897/AJBM11.

Aquilani, B., Silvestri, C., Ruggieri, A., \& Gatti, C. (2017). A systematic literature review on total quality management critical success factors and the identification of new avenues of research. The TQM Journal, 29(1), 184-213. https://doi.org/10.1108/TQM-01-2016-0003 
Baird, K., Su, S., \& Munir, R. (2018). The relationship between the enabling use of controls, employee empowerment, and performance. Personnel Review. https://doi.org/10.1108/PR-12-2016-0324

Bouranta, N., Psomas, E., Suárez-Barraza, M. F., \& Jaca, C. (2019). The key factors of total quality management in the service sector: a cross-cultural study. Benchmarking: An International Journal, 26(3), 893-921. https://doi.org/10.1108/BIJ-092017-0240

$\mathrm{Bu}, \mathrm{X} .-\mathrm{Z}$. , \& Cao, L. (2015). Study on the relationship between TQM implementation and corporate financial performance. 12th International Conference on Service Systems and Service Management, ICSSSM 2015. https://doi.org/10.1109/ICSSSM.2015.7170339

Cai, S. (2009). The importance of customer focus for organizational performance: a study of Chinese companies. International Journal of Quality \& Reliability Management, 26(4), 369-379. https://doi.org/10.1108/02656710910950351.

Chuang, S. S., Chen, K. S., \& Tsai, M. T. (2015). Exploring the antecedents that influence middle management employees' knowledge-sharing intentions in the context of total quality management implementations. Total Quality Management \& Business Excellence, 26(1-2), 108-122. https://doi.org/10.1080/14783363.2013.809941

Davenport, T. H. (2015). Process management for knowledge work. In Handbook on Business Process Management 1 (pp. 1735). Springer, Berlin, Heidelberg. https://doi.org/10.1007/978-3-642-45100-3 2

Deming, W. E. (1991). W. Edwards Deming. Madonna University.

Fening, F. A., Amaria, P., \& Frempong, E. O. (2016). Linkages between total quality management and organizational survival in manufacturing companies in Ghana. http://ir.csuc.edu.gh:8080/xmlui/handle/123456789/400.

Fotopoulos, C.B. \& Psomas, E.L., (2009). The impact of "soft" and "hard" TQM elements on quality management results. International Journal of Quality \& Reliability Management, 26(2), pp.150-163. https://doi.org/10.1108/02656710910928798

Gavareshki, M. H. K., Dabestani, R., \& Azar, A. S. O. (2019). Clustering employees on the basis of their perception from critical success factors of total quality management and its influence on customer focus. International Journal of Management Concepts and Philosophy, 12(2), 103-116. https://doi.org/10.1504/IJMCP.2019.099324

Golafzani, M. K., \& Chirani, E. (2016). Organizational culture and the financial performance of manufacturing firms. International Journal of Advanced Biotechnology and Research, 7, 1701-1711.

Idrus, A., Armanu, A. S., \& Rohman, F. (2015). The role of bureaucratic leadership, organizational culture, and organizational commitment on organizational performance (Study on the Local Government Task Force/SKPD's Financial Administration Officials in Jayapura City Government). European Journal of Business and Management, 7(19).

Johnson, O. T. (2004). Information theory and the central limit theorem (1st ed.). London: World Scientific. Jordan Securities Commission. (n.d.). Amman Stock Exchange. Retrieved from http://www.ase.com.jo/.

Jordan Investment Commission, https://www.jic.gov.jo/ar/2885-2/ Accessed on 21 /12/2019

Jyoti, J., Kour, S., \& Sharma, J. (2017). Impact of total quality services on financial performance: role of service profit chain. Total Quality Management \& Business Excellence, 28(7-8), 897-929. https://doi.org/10.1080/14783363.2016.1274649

Kaplan, R. S., Davenport, T. H., Robert, N. P. \& Norton, D. P. (2001). The strategy-focused organization: How balanced scorecard companies thrive in the new business environment. Harvard Business Press.

Khudhair, A. Z., Husseini, S. A., Fam, S.-F., Yahya, S. N., Ali Al-shami, S. S., Alantali, A. M., \& Alderei, S. K. (2019). The Effect of TQM in building customer loyalty in digital banking: A review. Religacion. Journal of Social Sciences and Humanities, 4(17). Retrieved from http://revista.religacion.com/index.php/about/article/view/276

Kiambati, J. G., Ngui, T., \& Mathenge, P. (2018). Employees Empowerment and Organizational Performance: A Case of Nyeri Catholic Secretariat. Journal of Human Resource \& Leadership, 2(5), 41-62. https://stratfordjournals.org/journals/index.php/journal-of-human-resource/article/view/217

Lado, A. A., Paulraj, A., \& Chen, I. J. (2011). Customer focus, supply-chain relational capabilities and performance: evidence from US manufacturing industries. The International Journal of Logistics Management, 22(2), $202-221$. https://doi.org/10.1108/09574091111156550

Luo, B., Groenke, K., Takors, R., Wandrey, C., \&Oldiges, M. (2007). Simultaneous determination of multiple intracellular metabolites in glycolysis, pentose phosphate pathway and tricarboxylic acid cycle by liquid chromatography-mass spectrometry. Journal of Chromatography A, 1147 (2), 153-164. https://doi.org/10.1016/j.chroma.2007.02.034.

Melo, T. (2012). Determinants of corporate social performance: the influence of organizational culture, management tenure and financial performance. Social Responsibility Journal. https://doi.org/10.1108/17471111211196557.

Nuryani, N. N. J., Windia, W., Susrusa, K. B., \& Suamba, I. K. (2016). Financial performance of sustainable farmers cooperative (Koptan) in Bali: Leadership, organizational culture, participation, budget and TQM. International Journal of Agriculture System, 4(2), 203-217. http://pasca.unhas.ac.id/ojs/index.php/ijas/article/download/693/188.

Parumasur, S.B. (2013). The importance of teamwork, continuous top management support and training in bringing about TQM. Journal of Economics and Behavioral Studies, $\quad$ 5(9), https://ojs.amhinternational.com/index.php/jebs/article/view/437.

Parvadavardini, S., Vivek, N., \& Devadasan, S. R. (2016). Impact of quality management practices on quality performance and financial performance: evidence from Indian manufacturing companies. Total Quality Management \& Business Excellence, 27(5/6), 507-530. https://doi.org/10.1080/14783363.2015.1015411 
Pattanayak, D., Koilakuntla, M., \& Punyatoya, P. (2017). Investigating the influence of TQM, service quality and market orientation on customer satisfaction and loyalty in the Indian banking sector. International Journal of Quality \& Reliability Management, 34(3), 362. https://doi.org/10.1108/IJQRM-04-2015-0057.

Psomas, E. L., \& Jaca, C. (2016). The impact of total quality management on service company performance: evidence from Spain. International Journal of Quality \& Reliability Management, 33(3), 380-398. https://doi.org/10.1108/IJQRM-072014-0090.

Saleem, M. A., Bhutta, Z. M., Nauman, M., \& Zahra, S. (2019). Enhancing performance and commitment through leadership and empowerment. International Journal of Bank Marketing, 37(1), 303-322. https://doi.org/10.1108/IJBM-02-2018-0037.

Sekaran, U., \& Bougie, R. (2016). Research methods for business: A skill building approach. John Wiley \& Sons.

Siehl, C., \& Martin, J. (1989). Organizational culture: A key to financial performance?. Graduate School of Business, Stanford University.

Wamalwa, L. S., Oloko, M. A., \& Owino, E. (2017). The Mediation Effects of TQM on the Relationship between Differentiation Strategy and Financial Performance of Manufacturing Firms in Kenya. http://erepo.usiu.ac.ke/11732/4259.

Yesil, S., \& Kaya, A. (2013). The effect of organizational culture on firm financial performance: Evidence from a developing country. Procedia-Social and Behavioral Sciences, 81, 428-437. https://doi.org/10.1016/j.sbspro.2013.06.455.

Young, R., \& Poon, S. (2013). Top management support-almost always necessary and sometimes sufficient for success: Findings from a fuzzy set analysis. International Journal of Project Management, 31(7), 943-957. https://doi.org/10.1016/j.ijproman.2012.11.013.

Zadeh, S. S. M. (2016). The Study of Role of Leadership Styles and Organizational Culture on the Financial Performance (Case Study: Mellat Bank's Branches in the Bushehr Province). International Journal of Humanities and Cultural Studies (IJHCS) ISSN 2356-5926, 1459-1468. http:/www.ijhcs.com/index.php/ijhcs/article/view/1303.

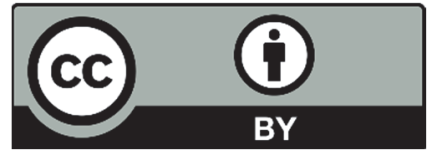

(C) 2021 by the authors; licensee Growing Science, Canada. This is an open access article distributed under the terms and conditions of the Creative Commons Attribution (CC-BY) license (http://creativecommons.org/licenses/by/4.0/). 